\title{
Bacterial infections in cirrhosis patients: a retrospective epidemiologic study in a greek university hospital
}

Maria Lagadinou* and Charalambos A. Gogos

*Correspondence: m_lagad2004@yahoo.gr

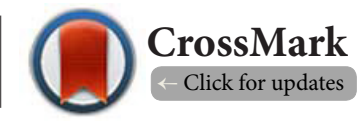

Department of Internal Medicine and Infectious Diseases, University Hospital of Patras, Greece.

\begin{abstract}
Introduction: Cirrhosis of liver is the end stage of multiple processes that lead to hepatic failure and eventually death. Patients with cirrhosis are immunocompromised and are predisposed to develop bacterial infections, sepsis and severe sepsis. The most common infections in cirrhosis are Spontaneous Bacterial Peritonitis (SBP, 25\%-31\%) followed by Urinary Tract Infection (UTI, 20\%-25\%), Pneumonia (15\%-21\%), Bacteremia (12\%) and Cellulitis (11\%). The aim of the study was to first identify the most frequent infections in patients with liver cirrhosis and evaluate the role of bacterial infections in clinical outcome of cirrhotic patients. We also tried to identify the most common cause of cirrhosis in our population.

Patients and methods: One hundred and ten (110) patients were included in our study. All of these patients had an established diagnosis of chronic liver failure and were admitted to the University hospital of Patras during a period of a year and a half. The following data were collected: Demographic characteristics (Age, Sex), Etiology of cirrhosis and the cause of admission. In specific interest the type of infection that was developed in all patients is included, as well as the frequency of those infections was observed.

Results: The mean age of all patients enrolled in our study was $61 \pm 13$ years. Alcoholic cirrhosis was the main factor-etiology of liver cirrhosis in our patient population. Male are significantly more than female patients $(87.3 \%$ vs $12.7 \%$ retrospectively). In our study, the most frequent infections were Pneumonia $(30.6 \%)$ and Spontaneous bacterial peritonitis (22.2\%) followed by Gastrointestinal infections (GI) (13.9\%) and Urinary tract infections (8.3\%). Other types of infection were up to $13.9 \%$. During the time of admission, there were 16 cases of bacterial infections diagnosed upon admission ( $<24$ hours) and 5 cases of infections developed during hospitalization (>48 hours). Mortality rate was $9 \%$ (10 cases).Ten patients with sepsis or severe sepsis have died. All of them were treated with broad spectrum antibiotics within 24 hours from admission.
\end{abstract}

Conclusion: The present study showed a high incidence of Bacterial infections in patients with liver cirrhosis. Patients with chronic liver disease sustained impairment to their immune system (neutrophil and macrophage dysfunction) which worsens over time and disease progression and the reason predisposed for developing Bacterial infections. A high rate of suspicion is needed for an infectious process in all patients with liver cirrhosis. With early diagnosis of the site of infection and the appropriate antibiotic treatment the morbidity and mortality rate of bacterial infections in cirrhotic patients, can be decreased over the years.

Keywords: Bacterial infections, cirrhosis, cirrhosis complications, spontaneous bacterial peritonitis

\section{Introduction}

Cirrhosis of liver is the end stage of multiple processes that lead to hepatic failure [1]. Approximately $40 \%$ of patients with cirrhosis are asymptomatic. That means, cirrhosis often is a silent disease, with most patients remaining asymptomatic until decompensation occurs [2]. Although increased mortality in cirrhosis is most often attributed to direct complications of the loss of liver function, a significant percentage mortality, succumb to bacterial infections, with infection-attributed mortality ranging from $7 \%-40 \%[1]$.

Patients with cirrhosis are immunocompromised and for that reason they are predisposed to developing bacterial infections,

(C) 2015 Lagadinou et al; licensee Herbert Publications Ltd. This is an Open Access article distributed under the terms of Creative Commons Attribution License (http://creativecommons.org/licenses/by/3.0). This permits unrestricted use, distribution, and reproduction in any medium, provided the original work is properly cited. 
sepsis and severe sepsis. The mechanisms of increased susceptibility to infections in cirrhosis are unclear: endothelial alteration, leukocytes dysfunction, bacterial translocation and iatrogenic factors are some of them [3].

Bacterial infection is a complication that occurs frequently in patients with cirrhosis. It may be present upon admission or it may appear during the hospitalization. It may be up to $30-60 \%$ of hospitalized patients [4,5]. In $30 \%$ to $50 \%$ of patients, infection is the cause for hospital admission in cirrhosis, while $15 \%$ to $35 \%$ develop nosocomial infections during their hospital stay as compared with $5 \%$ to $7 \%$ in the general hospital population [6]. The most common infections in cirrhosis are Spontaneous Bacterial Peritonitis (SBP, 25\%-31\%) followed by urinarytract Infection (UTI, 20\%-25\%), pneumonia (15\%-21\%), bacteremia (12\%) and cellulitis (11\%) $[7,8]$.

The aim of the study was first to identify the most frequent infections developed in patients with liver cirrhosis, as well as the most common cause of cirrhosis mentioned in our population.

\section{Patients and methods}

One hundred-ten (110) patients were included in that retrospective study. All of these patients had an established diagnosis of chronic liver failure and were admitted to the University hospital of Patras during a period of a one and half year.

The diagnosis of hepatic cirrhosis was based on clinical (splenomegaly, ascites, jaundice etc.), biochemical (increased liver enzymes), echographic findings (ultrasound) and/or data from liver biopsy.

The following data were collected: demographic characteristics (age, sex), etiology of cirrhosis and the cause of admission. In specific, interest, type of infection that was developed in all patients was included, as well as the frequency of those infections were observed. The diagnosis of Spontaneous bacterial peritonitis was made by finding more than 250 Neutrophils/ $\mathrm{mm}^{3}$ in ascitic fluid and/or positive cultures. Urinary tract infections were diagnosed through clinical symptoms (fever, haematuria, dysuria and frequent urination) and/or positive urine cultures and/or ultrasound findings. The diagnosis of pneumonia was established by symptoms and radiologic signs. For Bacteremia criteria like positive blood cultures, fever and hypotension were used and cellulitis was diagnosed by local sign (edema, redness, warmness) and/ or fever. In case of wound secretion, we evaluated positive cultures from the trauma.

We also collected the cirrhotic patients who died upon admission or during hospitalization. A statistical analysis was performed by using the Software Statistical Package for Social Science (SPSS), version 11.5. The values of the variables were expressed in terms of the mean value plus or minus the standard deviation.

\section{Results}

Demographic characteristics: One hundred and ten (110) patients with a history of cirrhosis were enrolled in our study. The mean age was $61 \pm 13$ years. Most patients were male (87.5\%). Female had a proportion about $12.7 \%$.

Etiology of cirrhosis, demographic characteristics and frequency of infections can be seen in Table 1.

As it is shown in the above Table 1, Alcoholic Cirrhosis is the main factor-etiology of liver cirrhosis in our patient population. Male are significantly more than female patients ( $87.3 \%$ vs $12.7 \%$ retrospectively). In our study, the most frequent infections were Pneumonia (30.6\%) and Spontaneous bacterial peritonitis (22.2\%) followed by Gastrointestinal infections (GI) (13.9\%) and Urinary tract infections (8.3\%). As it was shown from our study, the proportion of uncommon infections such as: Cholocystitis, Cholangitis, Lung abscess and Cellulitis, was remarkable up to $13.9 \%$. In $11 \%$ of cases the site of infection was not identified. The frequency of infection types are shown in Figure 1.

Table 1. Etiology of cirrhosis, Demographic characteristics and Frequency of infections developed in the group of patients.

\begin{tabular}{ll}
\hline Age(year) & $61 \pm 13$ \\
\hline Sex & \\
\hline Male & $87.3 \%$ \\
Female & $12.7 \%$ \\
\hline Etiology & $73 \%$ \\
\hline Alcohol & $18.9 \%$ \\
Viral (Hepatitis B ,C ,Both) & $2.7 \%$ \\
Unknown & $5.4 \%$ \\
Other & $21.5 \%$ \\
\hline Etiology of admission & $19.1 \%$ \\
\hline Infection & $59.1 \%$ \\
\hline Gastrointestinal (GI) bleeding & \\
Other (ascetic fluid, nausea, anaemia.....)
\end{tabular}

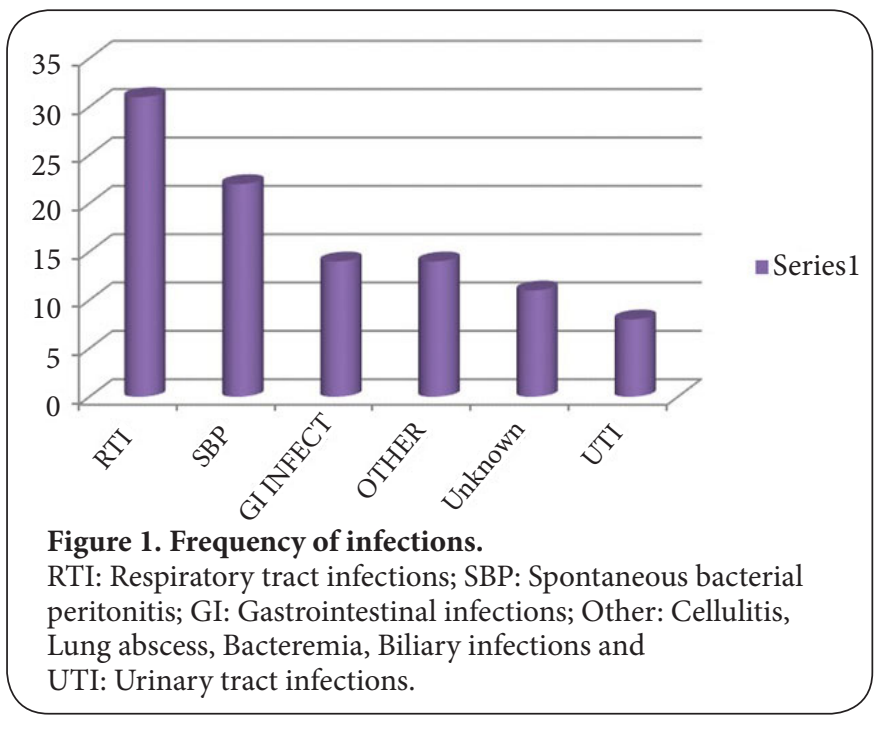


Sixteen (16) cases of Bacterial infections were diagnosed upon admission ( $<24$ hours) and 5 of them were developed during hospitalization ( $>48$ hours).

As it can be seen most infections were hospital acquired. Etiology agents were isolated in Blood cultures: $S$. epidermidis and E.coli and Urine cultures: E.coli, Candida albicans, Klebsiella pn. and Enterococcus faecalis.

Mortality rate was $9 \%$ (10 cases). Ten patients with sepsis or severe sepsis have died despite the fact that all were treated with broad spectrum antibiotics.

\section{Discussion}

The present study showed a high incidence of Bacterial infections in patients with Liver cirrhosis. Patients with chronic liver disease sustain impairment to their immune system (Neutrophil and Macrophage dysfunction) which worsens over time and with disease progression and the reason predisposed for developing Bacterial infections $[\mathbf{5}, \mathbf{9}]$.

According to the literature data about the frequency and distribution of bacterial infections in liver cirrhosis, Spontaneous bacterial peritonitis is the most frequent infection, followed by Urinary tract infections and Pneumonia $[3,4,6]$. Our results are a little differentiated in order from what is already published: Pneumonia was the most common infection (30.6\%), followed by Spontaneous bacterial peritonitis (22.2\%) and gastrointestinal infections (13.9\%), while Urinary tract infections frequency was (8.3\%).

According to the literature, the incidence of Spontaneous bacterial peritonitis is 25\%-31\%, Urinary Tract Infections are observed in $20 \%-25 \%$ of cases of infection, Pneumonia amounts to $15 \%-21 \%$, Bacteremia amounts to $12 \%$ and Cellulitis's frequency is $11 \%[7,8]$. In our study, the prevalence of each infection is more or less the same with that described in the literature so far, except UTI. In our study, we had one case of Lung abscess and one case of Biliary tract infection. The proportion of cases where the location of infection was not identified was $11 \%$. In conclusion, Urinary infections are less prevalent while Pneumonia is more prevalent in the present study, than in the literature.

It is written that $60 \%$ of Bacterial infections in cirrhotic patients are community acquired and $40 \%$ are Nosocomial [7]. According to Bruns et.al., Bacterial infections are diagnosed only in $25 \%$ to $47 \%$ hospitalized patients with cirrhosis [10]. Our results are similar to the data from literature, since $77 \%$ of infections were identified upon admission (less than 24 hours) and only $23 \%$ were developed during hospitalization (Nosocomial infections).

Bacterial infections are more frequent but also more severe in cirrhosis, causing an increase in the probability of death [3]. With Sepsis, mortality increases to more than 50\% [11]. Leber et al., have published that the mortality of SBP has decreased from $90 \%$ to $30 \%$. In contrast to non-cirrhotic subjects, Pneumonia has been shown to be more severe in patients with liver cirrhosis. Bacteremia is also a life-threatening disease in cirrhotic patients population, which increases the fatality rate. Cirrhosis has been shown to predispose the development of Bacteremia and to further significant impairment of prognosis in Bacteremic patients $[6,11]$.

Current study encountered some limitations. First, the sample size was small. Second, it was a clinical trial which took place in one center only. In the case of multi-center study, the results would be more representative. Third, in patients who died, we didn't take into account potential comorbidities.

In our study 10 deaths (9\%) were encountered in severe decompensated patients with Sepsis through Pneumonia, Bacteremia and Spontaneous bacterial peritonitis. Our results are in agreement with all so far publications referring to fatality rate in cirrhotic patients. Development of any type of infection in patients with liver cirrhosis, results in high overall mortality [12-14].

\section{Conclusion}

Infections are a major problem in patients with liver cirrhosis. This is a complication that worsens the already bad prognosis in this category of patients. A high rate of suspicion is needed for an infectious process in all patients with liver cirrhosis. Knowing the most frequent infections, based on our data and the existing literature, it facilitates and accelerates the diagnosis, resulting in faster initiation of appropriate treatment. With early diagnosis of the site of infection and the appropriate antibiotic treatment the morbidity and mortality rate of Bacterial infections in cirrhotic patients, can be decreased over the years.

\section{Competing interests}

The authors declare that they have no competing interests.

Authors' contributions

\begin{tabular}{|l|c|c|}
\hline Authors' contributions & ML & CAG \\
\hline Research concept and design & -- & $\checkmark$ \\
\hline Collection and/or assembly of data & $\checkmark$ & -- \\
\hline Data analysis and interpretation & $\checkmark$ & -- \\
\hline Writing the article & $\checkmark$ & $\checkmark$ \\
\hline Critical revision of the article & -- & $\checkmark$ \\
\hline Final approval of article & -- & $\checkmark$ \\
\hline Statistical analysis & $\checkmark$ & $\checkmark$ \\
\hline
\end{tabular}

Publication history

Editor: Amitis Ramezani, Pasteur Institute of Iran, Iran. Received: 13-Sep-2015 Final Revised: 14-Nov-2015

Accepted: 23-Nov-2015 Published: 30-Nov-2015

\section{References}

1. Christou L, Pappas $G$ and Falagas ME. Bacterial infection-related morbidity and mortality in cirrhosis. Am J Gastroenterol. 2007; 102:1510-7. | Article | PubMed

2. Heidelbaugh JJ and Bruderly M. Cirrhosis and chronic liver failure: part I. Diagnosis and evaluation. Am Fam Physician. 2006; 74:756-62. | Article I PubMed 
3. Acevedo $\mathrm{J}$ and Fernandez $\mathrm{J}$. New determinants of prognosis in bacterial infections in cirrhosis. World J Gastroenterol. 2014; 20:7252-9. | Article | PubMed Abstract | PubMed Full Text

4. Preda CM, Ghita R, Ghita C, Mindru C, Vlaicu L, Andrei A, Andrei S and Diculescu M. A retrospective study of bacterial infections in cirrhosis. Maedica (Buchar). 2011; 6:185-92. | PubMed Abstract | PubMed Full Text

5. Taneja SK and Dhiman RK. Prevention and management of bacterial infections in cirrhosis. Int J Hepatol. 2011; 2011:784540. | Article | PubMed Abstract I PubMed Full Text

6. Leber B, Spindelboeck W and Stadlbauer V. Infectious complications of acute and chronic liver disease. Semin Respir Crit Care Med. 2012; 33:8095. | Article | PubMed

7. Pleguezuelo M, Benitez JM, Jurado J, Montero JL and De la Mata M. Diagnosis and management of bacterial infections in decompensated cirrhosis. World J Hepatol. 2013; 5:16-25. | Article | PubMed Abstract | PubMed Full Text

8. Bunchorntavakul $\mathrm{C}$ and Chavalitdhamrong D. Bacterial infections other than spontaneous bacterial peritonitis in cirrhosis. World J Hepatol. 2012; 4:158-68. | Article | PubMed Abstract | PubMed Full Text

9. Wasmuth $\mathrm{HE}$, Kunz D, Yagmur E, Timmer-Stranghoner A, Vidacek D, Siewert E, Bach J, Geier A, Purucker EA, Gressner AM, Matern S and Lammert F. Patients with acute on chronic liver failure display "sepsislike" immune paralysis. J Hepatol. 2005; 42:195-201. | Article | PubMed

10. Bruns T, Zimmermann HW and Stallmach A. Risk factors and outcome of bacterial infections in cirrhosis. World J Gastroenterol. 2014; 20:2542-54. | Article | PubMed Abstract | PubMed Full Text

11. Bajaj JS, O'Leary JG, Wong F, Reddy KR and Kamath PS. Bacterial infections in end-stage liver disease: current challenges and future directions. Gut. 2012; 61:1219-25. | Article | PubMed Abstract | PubMed Full Text

12. Su CM, Chang WN, Tsai NW, Huang CR, Wang HC and Lu CH. Clinical features and outcome of community-acquired bacterial meningitis in adult patients with liver cirrhosis. Am J Med Sci. 2010; 340:452-6. I Article | PubMed

13. Cheng NC, Tai HC, Tang YB, Chang SC and Wang JT. Necrotising fasciitis: clinical features in patients with liver cirrhosis. Br J Plast Surg. 2005; 58:702-7. | Article | PubMed

14. Chen YM, Lee HC, Chang CM, Chuang YC and Ko WC. Clostridium bacteremia: emphasis on the poor prognosis in cirrhotic patients. J Microbiol Immunol Infect. 2001; 34:113-8. | Article | PubMed

\section{Citation:}

Lagadinou $\mathrm{M}$ and Gogos CA. Bacterial infections in cirrhosis patients: a retrospective epidemiologic study in a greek university hospital. Clin Hepatol Hepat Rep. 2015; 2:1. http://dx.doi.org/10.7243/2055-088X-2-1 